\title{
Analysis of Wakaf and Maqashid Syari'ah Law on the Development of Wakaf Property in Lhokseumawe City
}

\author{
Yasir Nasution ${ }^{1}$, Alyasa' Abubakar $^{2}$, Kafrawi $^{3}$ \\ 1,2,3 Universitas Islam Negeri Sumatera Utara, Indonesia
}

\begin{abstract}
:
The development of waqf assets in the form of adding the function of waqf is a new phenomenon in the problems of Islamic law jurisprudence even in positive law in Indonesia. In national law (positive), Indonesia has regulated this issue with the existence of laws and government regulations regarding waqf both movable and immovable waqf assets, even in its development every property in waqf must have an Deed and / or certificate. Whereas in Islamic jurisprudence, the development of waqf assets in the form of additional functions is one of the problems that can be said to be new, it needs legal conclusions and even has to be seen from various theoretical concepts such as maqashidu sharia. Therefore this research will examine the issue of developing waqf assets based on the Waqf Law and maqashid syari'ah. This research is an empirical legal research using a sociological legal approach, with data collection through documentation and interviews. The results of the research show that the development of waqf assets is permitted according to the law, but with the stipulated conditions, besides that the development of waqf assets is also permissible in Islamic jurisprudence as long as it is solely for reasons in accordance with the concept of maqasidu syari' ah and the point is to seek maslahat.
\end{abstract}

\section{Keywords:}

waqf; statute; maqasid syari'ah

\section{Introduction}

In the life of Islamic society in general, there is a relationship between humans and humans and a relationship between humans and their creators. The relationship between humans and humans is called muamalah. Meanwhile, the relationship between humans and their creators is called worship. However, between the relationship between humans and humans and the relationship between humans and their creators, there are also actions that contain muamalah, on the one hand, also have the value of worship, on the other hand, these actions are waqf.

Waqf has several meanings, among others, waqf is an eternal gift which is said with the sentence waqafa and not said in the sentence auqafa because it uses very little in language, and is said to be held back (Abi Husain Yahya). The same thing is also as said by Ibn Hajar, namely waqf according to language is al-habsu which means to hold. Whereas in the sense of syara 'is to hold property that allows it to benefit from it as well as its eternal life and to be used on the immortal. Waqf, on the one hand, is one of the ways the servant changes to his creator, because waqf is a commandment that is circumcised in the teachings of Islam. This can be understood from the letter al-Baqarah 267 and the letter Ali-Imran 92, as quoted by Abdul Mun'im Zainuddin.

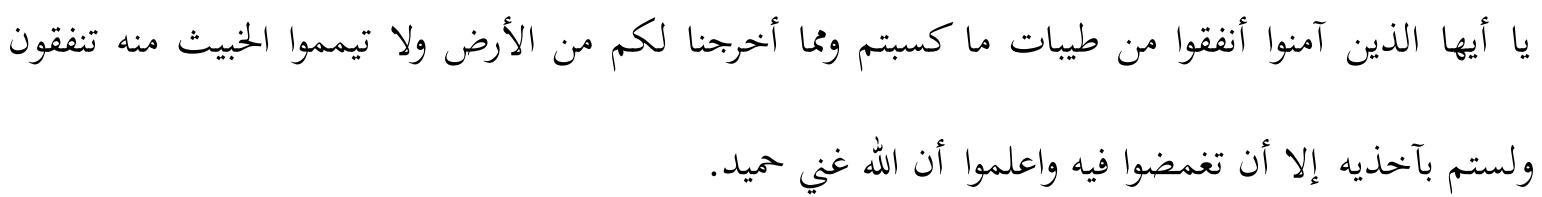


Meaning: O you who believe, spend (in the way of Allah) a portion of the results of your efforts are good and part of what We put out of the earth for you. And do not choose bad things and spend them, but you do not want to take them yourself but squinting at them, and know that Allah is rich, the most praiseworthy.(al-Baqarah 267)

. The position and function of the Qur'an other than as a holy book of the Qur'an is as a way of life for those who are pious and as a guide or guidance for humanity (Sinaga, 2020). If the Qur'an brought by the Prophet with their language, why they do not want to understand and ask the meaning, such as a variety of lessons and laws, so that they gain happiness in the world and the Hereafter (2020). The generality of the above verse clearly states infaq or income and giving something that is loved is a good thing and goodness can also be in the form of waqf. An understanding of the generality of the verse can be formulated with waqf based on the Prophet's traditions, one of which is as contained in the Sunan at-Tarmidzi about waqf Umar bin Khatab.

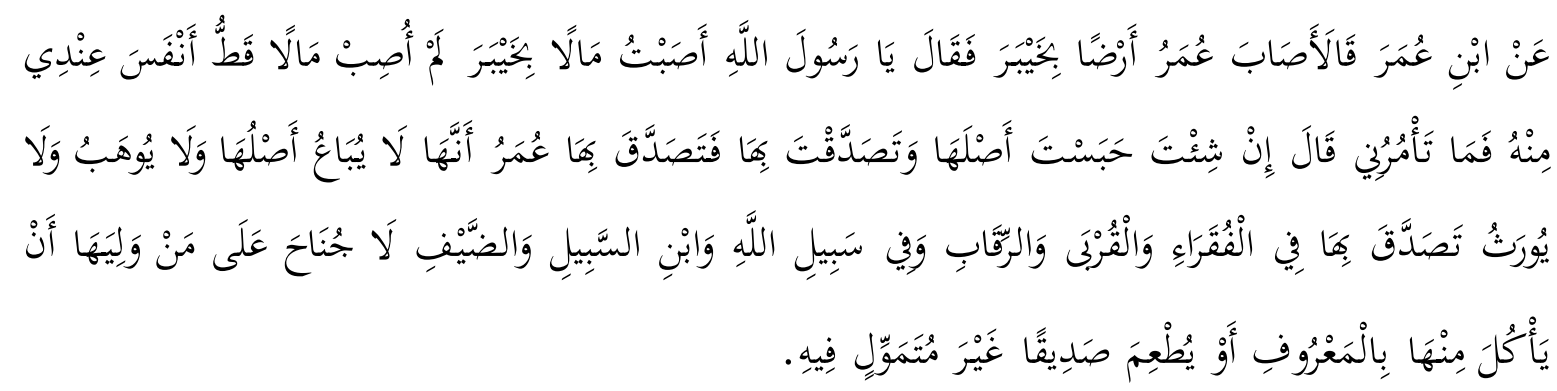

Meaning: From Ibn Umar he said; Umar once got a plot ofland in Khaibar, he also asked; O Messenger of Allah, I have found treasure in khaibar, I have never had a treasure that pleases my heart before like this, so what are you ordering me (on this treasure)? He replied, "If you please, hold on to the point and give charity to him", then Umar also gave alms to him, he did not sell his property, he did not give it, and he did not inherit it, and he donated it from the property to the poor, the expert of good relatives near and far, fi sabilillah, ibn sabil, and (the) guests. It is okay (without sin) for those who take care of that treasure if you take it from it to eat in a good way (reasonable), or feed a friend without selling (taking material profit) from him..

Waqf can improve and strengthen the relationship between humans and humans in muamalah, namely in terms of benefits when waqf assets are developed in accordance with the conditions and situations in a place. Waqf which is carried out by means of a sacrifice of property for the benefit of part of the community or the general public is also a form of worship.

During its development, waqf has become a strong socio-religious tradition in Indonesia. This cannot be denied because Indonesia is the majority of the population is Muslim, but in terms of its very minimal use, we can see the development of data contained in the Ministry of Religion of the Republic of Indonesia, namely the number of donated land in Indonesia reaches 2,686.536,656. 68 square meters or about 268,653.67 hectares (ha) spread over 366,595 locations throughout Indonesia, this amount of waqf land is the largest waqf property in the world. $23 \%$ of the assets used and managed in a productive direction, namely $77 \%$, are silent (https: // affgani). The development of waqf assets when viewed from the amount of waqf assets is relatively very small, it means that the waqf assets of the Muslims have not been developed proportionally and professionally. 
The use of waqf assets related to development to a more productive one has not been maximized. In general, the picture of waqf in Indonesia has not been managed with good and efficient management, so that its utilization and development only revolves around one particular aspect. The use of waqf assets is still dominated in the specific aspects of use, such as musalla and mosques, as shown in the data from the directorate of waqf empowerment, the use of waqf land for musalla $29.09 \%$, mosques $44.67 \%$, tombs $3.94 \%$, schools $10.81 \%$, pesantren $2.96 \%$, other social $8.53 \%$ (http://simbi.kemenag.go.id/siwak/). This data shows that the development of waqf has not been maximized.

From the general description of Indonesia above, it does not seem that much different from what happened in the regions, as in Aceh province. In Aceh, there are many educational institutions originating from waqf land, whether there are reports and data from the local Ministry of Religion (Regency / City) or not, both formal and non-formal educational institutions. There are educational institutions that are traditional in nature in the course of their development to have schools or even have campuses.

In particular, in Lhokseumawe City, the development of waqf assets in Lhokseumawe City can generally be seen in the data held by the Ministry of Religion of Lhokseumawe City, where the number of donated land locations spread across four Districts within the City of Lhokseumawe are 297 locations with the total area of the waqf land as 259.970 .58 square meters. Of the total waqf land, the most utilized or used is in places of worship such as mosques, musalla and meunasah, then educational facilities such as public schools, madrasahs, Islamic boarding schools, prayer centers, the rest are scattered in other social places. Of the many waqf lands / assets in the Lhokseumawe City area, especially those that are productive and are managed only to take advantage of the proceeds of the waqf assets, namely as many as 18 locations with an area of approximately $9792 \mathrm{~m} 2$. This productive land / waqf property is of various uses such as for shophouses, general Islamic religious purposes, mosque ric e fields, mosque asset gardens, and boarding houses (Kemenag Office, Lhokseumawe).

One example of the development of waqf land in the city of Lhokseumawe is in productive assets / waqf land, which is managed by Nadzir and other administrators, namely the Ulumuddin Dayah Islamic Boarding School, apart from Dayah UUlumuddin it is possible that other Dayahs also have the same problem. Based on preliminary observations, the authors see Nadzir as having developed the donated property / land that was donated by several waqf people for the benefit of Dayah Ulumuddin's establishment. In addition to the donated land, there is also an addition of the community group's donated land and BHA (Religious Property Agency) land. Departing from the donated land capital which covers an area of approximately 1.5 ha, now Dayah Ulumuddin has developed well, both the development seen from the side of the land area which now has reached approximately 8 ha, the number of buildings is increasing and the level of education starting from the level of elementary, middle and high school.

Based on the aforementioned problems, the shift related to waqf assets is growing rapidly, the addition of functions becomes a number of things that influence the development of Islamic law, of course there are many considerations from Muslim scholars (ulama) so that waqf assets are allowed to be developed, therefore it becomes a matter of It is interesting to study the development of waqf assets in terms of the Waqf Law and maqashidusy syari'ah as one of the concepts formulated by Imam Al-syatiby. 


\section{Research Methods}

\subsection{Development of Waqf Assets in Lhokseumawe City}

The development of waqf assets here is only in addition to the function of waqf, which the author wants to explain, among institutions and places where there has been development in terms of additional functions is a Dayah which functions as an institution for reading the thurat / bald book into an institution that has SD IT education for the community. children aged 7 to 12 years, MTs for children aged 12 to 15 years, MA and SMK for children aged 15 to 17 years. The current Dayah Ulumuddin education system teaches lessons based on the curriculum of the Ministry of Education and Culture and the Ministry of Religion, combined with the Traditional Daya curriculum and the Gontor Islamic Boarding School in the application of foreign languages. This dayah was originally named Dayah Ulumuddin as it was mentioned in AIW at the time of the waqf pledge. The author did not find documents at the Office of the Ministry of Religion of Lhokseumawe City, but this AIW was obtained from one of the heirs of the Siwakif. According to the explanation from Tgk H Syamaun Risyad Lc that Dayah, who has been running, has a building for recitation, dormitories and teachers as well as all levels of education are in accordance with the objectives of siwakif. As for the implementation of its development (adding to the level of education) Nadhir does not carry out further deliberation process with the wakifs, so it is only the authority of Nadir itself. In its journey, of course, it has also developed into an educational institution that accommodates children from all walks of life, both those who are able and poor.

\section{Discussion}

\subsection{Analysis of the Waqf Law on the Development of Waqf Assets in Lhokseumawe City}

In the regulations that apply to the territory of the Unitary State of the Republic of Indonesia, of course, the legal mechanism for waqf and the procedure for changing the land of the waqf is regulated. Waqf assets must be used in accordance with what is stated by the siwakif or the purpose of the waqf. This cannot be separated from the understanding of the sound of the waqf law as in Article 40:

1. Make a guarantee;

2. confiscated;

3. granted;

4. on sale;

5. be inherited;

6. exchanged; or transferred in the form of other transfer of rights.

Thus, if you look at the law above, it is very clear and firm that no actions that can diminish the basic function of waqf, whether the object or its benefits are lost. If there is a need for a change in function in managing waqf assets, then it must follow the steps mandated by the applicable law as referred to in Article 44, paragraphs 1 and 2, among others (Laws and Regulations, 2012).

(1) In managing and developing waqf property, Nazhir is prohibited from making changes to the allocation of the waqf property except on the basis of a written permission from the Indonesian Waqf Board.

(2) The license as referred to in paragraph (1) can only be granted if the waqf property cannot be used in accordance with the allotment stated in the waqf pledge. 
Based on paragraph 2 above, it shows that actually waqf assets must be used in accordance with what has been written in AIW in accordance with the purpose of waqf. Then from the explanation above, it can be seen that the addition process did not follow the steps stipulated in Law No. 41 of 2004.

All waqf activities in effect in the State of Indonesia, in the case of developing waqf property, it cannot separate from the allocation of the waqf property itself as regulated and continues to carry out the stages and mechanisms stipulated in Article 6 of the Waqf Law. shows clarity that in fact the use / addition of functions of waqf property must be in accordance with the objectives of the waqf itself as set forth in the AIW / waqf certificate when it is pledged. So when additions are to be made, it is necessary to carry out the steps of the applicable rules, not directly carry out what is considered good in the development of waqf assets.

(1) Nazhir is obliged to manage and develop waqf assets in accordance with the allotment stated in AIW.

(2) In managing and developing waqf assets as referred to in paragraph (1) to promote public welfare, Nazhir may cooperate with other parties in accordance with sharia principles.

And Article 48, namely "Management and development of waqf assets must be guided by regulations BWI (Laws and Regulations, 2012).

Based on the law and the PP regarding waqf above, it has shown that all forms of changes to the basis of waqf can be carried out only by predetermined mechanisms and stages, meaning that apart from this process, the state in its capacity as the organizer of the law cannot accept and justify it. Thus the addition of the function of waqf even though it has more benefits, it needs to be done according to the applicable regulations. Here the state is present to arrange so that waqf assets are not misused by irresponsible parties in places that are not in line with sharia. Here, when viewed from the point of view of the applicable laws and regulations, it is included in the prohibited category in accordance with the provisions of Article 44 paragraph 2 of the Waqf Law, that is the permit as referred to in paragraph (1) can only be granted if the waqf property cannot be used in accordance with the allotment stated in the waqf pledge (Legislation, 2012).

\subsection{Analysis of Maqashid Sharia on the Development of Waqf Assets in Lhokseumawe City}

Talking about waqf is inseparable from the syara 'passages, both those contained in the Koran and in the Assunnah, as stated in the texts which are written "Tunfiqũ", "al-Bir", and "Sadaqatun Jãriatun", p. This shows clearly that waqf is something that is implied without any doubt. The text of this argument both contained in the Koran and the Assunnah is a form of appeal / invitation to provide infaq and assistance in the context of legal legitimacy so that it can help people who need help and a helping hand from people who have more abilities, and spend assets / money for the general good. The position of waqf in Islam is the same as zakat, in relation to distributing a portion of the excess of the people who are more to those who are needy and weak.

Then in developing waqf, it can be done in innovative ways in various productive forms so that the benefits of waqf can be felt more and in accordance with the times and circumstances. Waqf development in order to be moreproductive in accordance with the times and circumstances, it is very necessary to pay attention and be carried out in accordance with the concept of sharia, so as not to lose the basic purpose of waqf. The right step in developing waqf at this time is to use the concept of maqãsid syarĩ'ah. Because actually the shari'ah is 
aimed at realizing the benefit of mankind in the world and in the hereafter and the laws are prescribed for the benefit of the servant. With the understanding, that the content of maqãshid syarî'ah is for the benefit of mankind. Maqasad or the stated purpose of waqf is for the good of Islam. Therefore, anything that brings goodness to humans, both Islam and nonIslam, even for the good of animals and the natural surroundings is also included in the category waqf.

The needs of the community which will determine in which direction the waqf property will be used and developed based on the maqasad mentioned, will become waqf. Waqf is not only focused on certain good deeds, it even includes all kinds of good deeds as long as it can be done for the benefit of mankind. As Allah mentions in Alhajj 77, as follows:

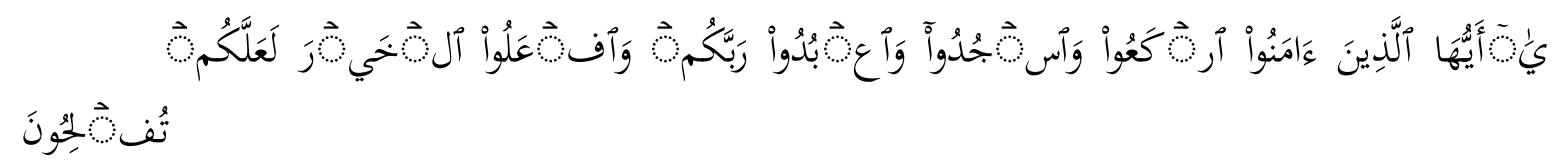

This verse can be understood by the maqasid waqf which belongs to the category of doing good, so it includes all kinds of good wherever and whenever. Thus the maqasid of developing waqf is doing good, activating the use of goodness and spreading its goodness so that it develops better and better. After understanding what the maqasid of sharia is, the link between waqf and maqasid is easy to explain.

The development of waqf plays a role in ensuring the existence of the five basic rights of khamsah (or basic needs), namely maintaining religion, soul, mind, honor and property. Likewise in maintaining hajiyyah (or necessities) and restraining all difficulties, besides maintaining tahsiniyyah (or perfection). Many verses tell people to take care of themselves and help spread goodness and make goodness like the word of Allah in al-Ma'idah 2:

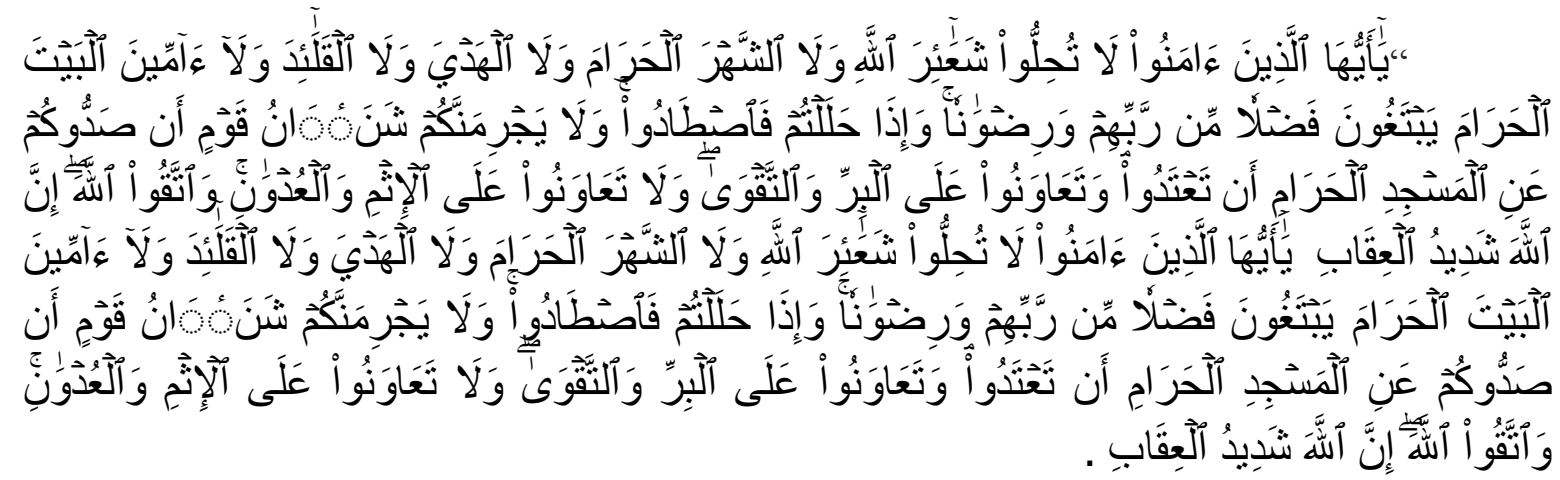

The concept of waqf development is closely related to maqāsid asy-syari'ah (maqasid hajjiyat), because in a simple sense maqāsid asy-syari'ah is a means to find maslahat (Abi Ishaq Ibrahim, 2004). The development of waqf is one form that is carried out in order to create the benefit of the people, a concrete example of this maqasid syari'ah is the total protection of five points, namely:

a. Protection of religion (hifdhun din)

In the review, the protection of religion here is to develop in relation to the addition of the function of waqf which can be felt in increasing people's understanding of religious teachings in a comprehensive manner from science, so as to give birth to a generation of people who believe and believe in Allah SWT. 
b. Protection of the soul (hifdhun nafs)

The development of waqf here can also be seen from the impact on the protection of the souls of the people who take their education on the Dayah. Because with the existence of an institution that provides complete educational facilities, a combination of traditional, modern Dayah curricula, the Ministry of Religion and the Ministry of Education and Culture, many children can be saved from the influence of the free outside world.

c. Protection of sense (hifdhun akli)

It is to educate the public from the ignorance of understanding religion and other sciences.

d. Protection of offspring (hifdhun nasl)

Here too, the existence of an integrated educational institution such as Dayah Ulumuddin will benefit the sustainability of a good generation in the future because it has a combination of scientific fields.

e. Protection of property (hifdhul mal)

The latter is one of the right steps to make waqf assets more beneficial for the community in addition to other needs, while at the same time keeping these assets intact and growing.

From the provisions of maqāsid asy-syari'ah, indirectly, the provision in the addition of the function of the donated land is to realize the general benefit and protect the assets of the waqf from being of less use to those that are more beneficial than the value of benefit. So thus the addition of functions here, even though it does not refer to the applicable law, can still be justified by looking at the concept of maqāsid asy-syari'ah.

This is based on the law of fiqh which reads:

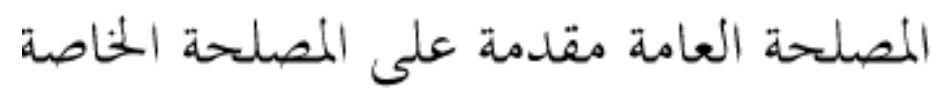

The above rule emphasizes that if there is a collision between the general benefit and the special benefit, then the general benefit must take precedence, because in the general benefit there is also a special benefit, but not the other way around (Abi Ishaq Ibrahim, 2004).

\section{Conclusion}

The development of waqf assets in the form of additional functions must go through the balance of maqashid sharia, especially those related to hifdhul maal and hifdhul diin and in accordance with maqashid hajjiyyat, besides that the provisions of laws and regulations relating to waqf are also things that must be considered because the development of waqf assets requires legality and recognized by the State, so that later there would be no disputes between the heirs of Wakif and Nazhir.

The provisions in law and maqashid sharia must of course go hand in hand in order to prevent problems that arise in the future, community leaders as well as those who donate and heirs must understand the essence of waqf assets, assets that have been donated do not mean they cannot be transferred, but of course with the provisions of both the Sharia and the State. 


\section{References}

Abdul Mun'im Zainuddin, Dhawãbithu al-Mãli al-Mauqũfi, (Beirut: Dar an-Nawãdir, 2012 M/ $1433 \mathrm{H})$.

Abi Husain Yahya ibn Abi al-Ghair ibn Salim al-I'mran as-Syafi'I al-Yamani, Al-Bayan fi alMazhabal-Imam as-Syafi'I, jilid VII (Dar al-Minhaji, ttp).

Abi Isa Muhammad bin Isa AT-Tarmizi, Al- Jami’ al- Kabir, juz IV, (Beirut: Dar al- Gharb alIslam, 1998).

Abi Ishaq Ibrahim ibn Musa ibn Muhammad al-Lakhmi asy-Syathibi, Al-Muwāfaqāat fi Usūl asy-Syari'ah, , (Beirut: Dar al Kutub al Imiyah, 2004).

Abi Zakaria Yahya ibn Syiraf an-Nawawi ad-Damsyiqi, Raudhatu at-Thalibin, jilid IV, (Beirut:Dar al- Kutub al-Ilmiyah, 2003).

Dr. Munzir Qahaf, Managemen Wakaf Produktif, (Jakarta Timur: Khalifa, Pustaka al Kautsar group).

Himpunan Peraturan Perundang undangan, Undang Undang Pengelolaan Zakat dan Wakaf, (Bandung: Fokus Media, 2012).

Muhammad Abu Zahrah, Muhãdharãti fi waqfi, (Jami’ah Dar Arabiyah Ma'had Dirasah Arabiyah Aliyah, 1909).

Nirwana, A., Hayati, and Ridwan, M. (2020). The Media of Washatiyah Dakwah in Quranic Exegesis Study. Budapest International Research and Critics Institute-Journal (BIRCIJournal) Vol 3 (2): 911-922.

Sinaga, A.I., Ananda, R., and Putri, H.A. (2020). The Role of the Manager of the Qur'an House 'Aisyah Radhiyallahu' Anha in Applying the Living Qur'an Method in Bangun Sari Village, Tanjung Morawa District, Deli SerdangRegency North Sumatra. Budapest International Research and Critics Institute-Journal (BIRCI-Journal) Vol 3, (3): 1718 1723.

Internet

https://affgani. Wordpress.com/ekonomi-islam/wakaf-memberdayakan ummat/ 04-05-15

http://simbi.kemenag.go.id/siwak/ 04-05-15 